Environmental Science \& Policy

April 2016, Volume 58 Pages 141-154

http://dx.doi.org/10.1016/i.envsci.2016.01.016

http://archimer.ifremer.fr/doc/00311/42202/

(c) 2016 Elsevier Ltd. All rights reserved.

\title{
Long-term water quality in the lower Seine: Lessons learned over 4 decades of monitoring
}

\author{
Romero Estela ${ }^{1,{ }^{*}}$, Le Gendre Romain ${ }^{2}$, Garnier Josette ${ }^{1,3}$, Billen Gilles ${ }^{1,3}$, Fisson Cédric ${ }^{4}$, \\ Silvestre Marie ${ }^{5}$, Riou Philippe ${ }^{6}$
}

${ }^{1}$ Université Pierre et Marie Curie (UPMC), UMR 7619 Metis, Paris, 75005, France

${ }^{2}$ IFREMER, Unité de Recherche Lagons, Ecosystèmes et Aquaculture Durable, Nouméa, 98848, New-

Caledonia, France

${ }^{3}$ CNRS, UMR 7619 Metis, Paris, 75005, France

${ }^{4}$ Groupement d'Intérêt Public Seine-Aval (GIP-Seine-Aval), Pôle Régional des Savoirs, Rouen, 76100,

France

${ }^{5}$ CNRS, FR3020 Fédération Île-de-France de Recherche sur l'Environnement (FIRE), Paris, 75005,

France

${ }^{6}$ IFREMER, Laboratoire Environnement et Ressources de Normandie, Port en Bessin, 14520, France

*Corresponding author : Estela Romero, email address : estela.romero@upmc.fr

\begin{abstract}
:
The Seine River is a highly artificialised catchment in Europe, comprising both productive agricultural areas and intense industrial and commercial activity. Due to its strategic importance, monitoring programs in the river started as early as the 1970s. The present study compiles and analyses this valuable data set (1970-2014), thoroughly describing the riverine section downstream of Paris and the estuary. We identify long-term trends and shifting patterns in nutrients and oxygen, and pay special attention to the river's evolution after the year 2000, when the European Water Framework Directive came into force. The study has a manifest management perspective, and the results are discussed on the basis of the environmental quality standards proposed in current environmental regulations. The data show that water quality has improved remarkably over the past two decades, with sharp reductions of ammonium and phosphate and a progressive increase of dissolved oxygen levels. The amelioration is prominent in the estuary, where summer anoxic episodes have nearly disappeared. As a result, these three parameters are nowadays in good or very good condition throughout the year. The successful abatement of point sources contrasts, however, with the low effectiveness of the measures provided for the control of nutrients from diffuse sources. Nitrate concentration has increased by $150 \%$ since the early 1980s, and only very recently has the upward trend been reversed. Bold agri-environmental management measures are required if we are to prevent chronic pollution problems and truly restore the good ecological status of rivers.
\end{abstract}




\section{Highlights}

- Evolution of the water quality in the lower Seine over the last 40 years. Impact of human activities and water management practices on nutrient concentrations. Comparison of seasonal and long-term patterns in the riverine and estuarine sectors. Evolution and effectiveness of freshwater quality policies in the Seine River.

Keywords : Seine River, Water quality, Nutrients, Long-term trends, WFD, Policy 


\section{INTRODUCTION}

The Seine River is a highly artificialised catchment in Europe. The upper Seine drains extensive, productive agricultural areas, while the lower part flows across the Paris conurbation, with over 10 million inhabitants, and the Rouen-Le Havre axis, which hosts intense industrial and commercial activity (Meybeck et al., 1998; Billen et al., 2001). The river plays a critical role in numerous aspects of human activity, providing resources (water, food, raw materials) and transportation, and these strategic advantages account for the presence of large human settlements in the region for several centuries (Billen et al., 2007 and references therein).

The importance of the river and its related resources has sparked monitoring activities since the 1950s, which evolved into regular surveys with a bi-monthly frequency after 1970 . As a result, the Seine River offers a unique and very complete database that allows a thorough examination of the river's evolution during the past half-century, coupling changes in water quality with major socio-economic and technological changes. Billen et al. $(2001,2007)$ used the Riverstrahler model to assess the biogeochemical functioning of the basin and presented an overview on the dynamics of the river system, although none or very few data were included on the estuary. Herein, we do not adopt a mechanistic approach, but rather scrutinise the actual quality data set with a number of statistical techniques, including not only the riverine section downstream of Paris, but also the estuary. We aim to detect trends, turning points and shifting patterns, providing a complete description of the lower reach of the river. We track concentrations over a long period of time (1970-2014) and establish trajectories that can be paralleled to the trajectories observed in human systems. Furthermore, we have updated the analyses until the most recent years and pay special attention to the evolution after the year 2000, when the application of the Water Framework Directive (hereafter, WFD) promoted new advances in the basin's wastewater treatment plants (e.g. in Achères, the largest sewage facility, phosphorus abatement was implemented in 2000, nitrification in 2007 and denitrification in 2011).

The study has a manifest management perspective: we use the concentration ranges recommended in European and French national regulations and discuss the corresponding quality status categories. The WFD requires all waters to reach 'good ecological status' by 2015 , so our results may contribute to verifying the compliance of this demand for the Seine.

Please cite this article as doi: 10.1016/j.envsci.2016.01.016

This article is protected by copyright. All rights reserved. 
Our ultimate goals are to assess the efficacy of the water management measures applied thus far, identify major weaknesses and suggest potential improvements.

An additional asset of the study is the integrated assessment of the river stream and the estuary, considering the interplay between the freshwater and the marine reaches. Given the complexity of estuarine systems, policies focused on river water quality rarely consider the effects and synergies with the river mouth and the nearby coastal strip. The role of estuaries in buffering the nutrient load to coastal waters, however, can be significant (e.g., Canton et al., 2012; Soetaert et al., 2006). In the Seine Bight, Garnier et al. (2010) found that the estuary is able to retain (either as permanent or temporary storage, or as definitive elimination) nearly $7 \%$ of the annual $\mathrm{N}$ inputs (the abatement reaching $40 \%$ during the summer months), $4 \%$ of dissolved silica inputs and over $30 \%$ of inorganic $P$ inputs. Moreover, transit through the estuary changes not only the concentration of inorganic nutrients, but also many other compounds, including a myriad of micropollutants in their dissolved and particulate forms. The results presented here - comprising data from 22 estuarine stations - allow testing some of the conjectures put forward in previous studies on the role of the Seine estuary (Even et al., 2007; Garnier et al., 2008; Némery \& Garnier, 2007), namely the low retention capacity with respect to the upstream nutrient fluxes. The next step will be the use of these data to calibrate a functional model to represent the biogeochemical processes occurring in estuarine waters more closely and to quantify the retention/export of the different elements in the estuary, given that the Seine is a good representative of the macrotidal estuaries typical of the European Atlantic façade. For that purpose, the ecological modelling chain used in Passy et al. (2016) to represent the land-sea continuum will take into account the estuarine compartment.

\section{MATERIALS AND METHODS}

\subsection{The study area}

A few basic characteristics of the Seine basin (as a whole and for the specific river stretch under study) are presented in Table 1. Briefly, the river and its estuary drain an area covering $76,260 \mathrm{~km}^{2}$, and the main branch is over $760 \mathrm{~km}$ long. After Paris, the river flows to the northwest and drains its water into the English Channel (Fig. 1). The region presents a typical temperate-oceanic climate, with a mean annual precipitation of $680 \mathrm{~mm}$ uniformly distributed throughout the year.

The lower Seine River, from Paris to Poses, is about $360 \mathrm{~km}$ long and is strongly influenced by the Paris conurbation, which accommodates ca. 12 million inhabitants. Urban effluents from the city are treated in various wastewater treatment plants (WWTPs), whose capacity and types of treatment have been deeply modified during the last decade. The largest one (Seine Aval, located in Achères, $74 \mathrm{~km}$ downstream of Paris) treats about 1.67 million $\mathrm{m}^{3} \mathrm{~d}^{-1}$ (i.e. 6.5 million equiv. inhab.), the rest of the wastewater being distributed among three other facilities $\left(0.6,0.3\right.$ and 0.24 million $\left.\mathrm{m}^{3} \mathrm{~d}^{-1}\right)$.

The estuary itself occupies $50 \mathrm{~km}^{2}$ (the third largest estuary in France), and the intraestuarine basin accounts for ca. $6 \%$ of the total surface of the catchment $\left(\sim 4515 \mathrm{~km}^{2}\right.$, Garnier et al., 2013a). The population of the estuarine basin is about 1 million inhabitants. A large wastewater treatment unit (Émeraude WWTP) treats the wastewater from Rouen city and its conurbation ( 0.085 million $\mathrm{m}^{3} \mathrm{~d}^{-1}$, i.e. 0.7 million equiv. inhab.). The estuary is composed of two major sections: a freshwater tidal sector - from Poses to Caudebec - and a lower part affected by a salinity gradient (Fig. 1). The tides influence the estuary up to Poses, where a 
lock prevents further tidal propagation (Fisson et al., 2014; Garnier et al., 2010). Broadly, tidal amplitudes vary between 3-7 $\mathrm{m}$ at Honfleur and 1-2 $\mathrm{m}$ at Poses, and the mean residence time in the estuary spans from 17-18 days for a discharge of $200 \mathrm{~m}^{3} \cdot \mathrm{s}^{-1}$ at Poses to 5-7 days for a discharge of $1000 \mathrm{~m}^{3} \cdot \mathrm{s}^{-1}$ (Even et al., 2007; Le Hir et al., 1999). The estuary is also characterised by the formation of a turbidity maximum zone (TMZ). The TMZ is mostly located between Honfleur and Tancarville, but it can move upstream depending on both the tide cycle and the river discharge. During winter flood events, the TMZ is usually flushed out into the Seine Bight (Etcheber et al., 2007; Garnier et al., 2008; 2010).

Numerous morphological alterations have taken place during the past century aiming at facilitating navigation (Foussard et al., 2010; Lafite \& Romaña, 2001; Lafite et al., 2007). A number of dikes and locks have been installed, and many canals have been dredged to increase the depth of the waterways. In addition, huge engineering works designed to improve the access of the Rouen and Le Havre harbours have led to a large amount of sediment removal (Lesourd et al., 2001; Némery \& Garnier, 2007).

Despite the large human settlements located in the lower reaches of the river, the Seine catchment and its estuary are mostly composed of agricultural land, notably cereals and industrial crops. According to Garnier et al. (2013a), forests cover about $25.8 \%$ and $20.5 \%$ of the total area (for the basin and the estuary, respectively), arable land represents $52.7 \%$ and $42.9 \%$, and grasslands and meadows account for $10 \%$ in the river basin and $26.4 \%$ in the estuary, where cattle breeding is a significant activity.

In concordance with these physical and socio-economic drivers, we have split the river stretch between Paris and Honfleur into six sections (Fig. 1). Briefly, sections 1-2 correspond to the marine-influenced estuary, sections 3-4 correspond to the freshwater tidal estuary and sections 5-6 cover riverine segments located downstream and upstream of the largest sewage facility.

\subsection{Time series of river discharge and water quality data}

River flow data (1955-2014) were provided by the Ministry for Ecology and Sustainable Development through the French national hydrologic databank (Banque HYDRO, www.hydro.eaufrance.fr). Daily measurements of river discharge were obtained from two gauging stations: one in Paris, the most upstream location of our study section, and one in Poses, at the interface between the river and the estuary (Fig. 1).

Water quality data were collected from 45 stations along the river, 22 of them within the estuary (from Poses to Honfleur) and 23 upstream of the estuary (from Paris to Poses), as shown in Figure 1 . The available data (from $<10$ parameters in some stations during the winter time, to over 200 parameters), the sampling frequency (weekly or fortnightly in key locations, every two months in the least sampled stations), and the length of the data series (between 20 and 1494 total records) changed from one station to another, in some cases starting as early as 1955, and most often in 1970. Quality data were provided by the Service de Navigation de la Seine (SNS) and the Seine water authority (AESN, Agence de l'Eau SeineNormandie). The monitoring scheme measures up to 202 variables, including a wide range of organic pollutants in both the water column and the sediments, although for the purpose of this study only a few parameters related to nutrient transformations were explored.

Flow-adjusted nutrient fluxes. The annual load of nutrients delivered by the river to the estuary was calculated using flow-adjusted concentrations, as is generally recommended in guidelines and official reports dealing with river water quality (e.g. Convention for the protection of the marine environment of the North-East Atlantic, OSPAR 1998). We used the 
flow and nutrient concentrations at Poses, the most downstream station not influenced by tides. Fluxes were obtained applying the formula:

$$
\text { Flux }=Q_{m} \cdot\left(K \cdot \Sigma\left(C_{i} \cdot Q_{i}\right) / \Sigma Q_{i}\right)
$$

where $\mathrm{K}$ is a conversion factor to take into account the desired period (in our case, 365 days), $\mathrm{C}_{\mathrm{i}}$ the instantaneous concentration, $\mathrm{Q}_{\mathrm{i}}$ the instantaneous discharge at the time of sampling, and $Q_{m}$ the mean water flow for the period considered (annual, biannual, quarterly, etc.).

\subsection{Statistical analyses}

Seasonal patterns and long-term trends were obtained following the Seasonal-Trend decomposition procedure based on LOESS (STL method, Cleveland \& Devlin, 1988; Cleveland et al., 1990). This method has been applied to analyse time series in many different domains (e.g. Li et al., 2003; Lu et al., 2012; Seebens et al., 2007) and notably to assess the variability of water quality data sets in rivers (Qian et al., 2000; Lloyd et al., 2014). Broadly, the STL filtering method decomposes the time series into seasonal (cyclic), trend and residual components by means of nonparametric regressions. It is very useful to describe nonlinear patterns that do not have an obvious functional form, and it provides a robust statistical estimation of seasonal and trend components, buffering the effect of outliers and aberrant data.

The implementation of this technique involves a few parameters that determine the degree of smoothing in both trend and seasonal components. Following the recommendations and diagnostic methods reported by Cleveland et al. (1990), and given the number and frequency of our observations, we set window widths of 15 months and 41 months for the seasonal and long-term components, respectively. To work with regularly spaced data, we calculated median monthly values for those stations with more than one measurement per month.

All analyses were performed in JMP (SAS Institute Inc.), R (http://CRAN.R-project.org) and Matlab (The MathWorks Inc.).

\section{RESULTS}

\subsection{River flow patterns}

Over the 1970-2014 period, the average flow of the Seine River in Paris was about 300 $\mathrm{m}^{3} \cdot \mathrm{s}^{-1}$, and increased to $467 \mathrm{~m}^{3} \cdot \mathrm{s}^{-1}$ at the entrance of the estuary (Poses) due to the confluence with the Oise River. There were marked intra-annual differences between winter and summer flows (at Poses, $726 \mathrm{~m}^{3} \cdot \mathrm{s}^{-1}$ in the winter and $249 \mathrm{~m}^{3} \cdot \mathrm{s}^{-1}$ in the summer), and between wet and dry years (two- to three-fold differences, Fig. 2). Note that here we define wet and dry years as those with an annual discharge higher or lower than the mean \pm 1 standard deviation of the whole time series. A small but significant long-term increase of flow is observed throughout the past 50 years ( $p$-value<0.001). This increase was previously pointed out by Massei et al. (2010), who attribute the long-term flow increase to concomitant changes in the pluviometric regime, and thus to a climatic origin.

\subsection{Evolution of water quality parameters: trajectories}

Figure 3 shows the evolution of inorganic nutrients, chlorophyll and oxygen for the entire set of stations (Paris to the mouth of the estuary, at Honfleur), from the 1970s to the present. A few clear patterns appear during the first few decades, in agreement with previous studies 
on the basin (see e.g., Billen et al., 2007), although many trends have markedly shifted in the past few years and are shown here for the first time:

(i) The highest concentrations of phosphate and ammonium were recorded in the Seine before the 1980s, mainly in the estuary. Average values were as high as $2.1 \mathrm{mg} \cdot \mathrm{L}^{-1}$ for phosphates and $2.1 \mathrm{mg} \mathrm{NH}_{4}^{+} \cdot \mathrm{L}^{-1}$ for ammonium. Values of nitrate during the same period were the lowest of the time series but were already high, on the order of $15 \mathrm{mg} \mathrm{NO}_{3} \cdot \mathrm{L}^{-1}$, higher than the recommended level for good ecological status of 9-10 $\mathrm{mg} \mathrm{NO}_{3} \cdot \mathrm{L}^{-1}$ (European Directives 91/676/EEC; 91/271/EEC; 96/61/EEC; 2000/60/EC).

(ii) From the 1980s to the early 1990s, high values of ammonium and particularly of phosphate spread along the river axis, with remarkable peaks downstream of the Paris and Rouen conurbations. Nitrate concentrations increased with regard to the previous years (on average, $\left.21 \mathrm{mg} \cdot \mathrm{L}^{-1}\right)$, the highest levels persistently occurring in the estuarine sector $(\sim 23$ $\mathrm{mg} \cdot \mathrm{L}^{-1}$ and $\sim 19 \mathrm{mg} \cdot \mathrm{L}^{-1}$ downstream and upstream of Poses, respectively).

(iii) Substantial changes occurred during the second half of the 1990s and the early 2000s, notably for nitrate and phosphate concentrations. Phosphate decreased to an average value of $0.7 \mathrm{mg} \cdot \mathrm{L}^{-1}$ (present values are $<0.3 \mathrm{mg} \cdot \mathrm{L}^{-1}$ ), while nitrate concentrations increased in all measuring stations to mean annual values above $20 \mathrm{mg} \cdot \mathrm{L}^{-1}$.

(iv) A sharp shift is further observed after 2007 downstream of the Achères WWTP for nitrate and ammonium; the latter has dropped to very low values (on average 0.3 , and $\sim 1 \mathrm{mg}$ $\mathrm{NH}_{4}+\mathrm{L}^{-1}$ close to the sewage facility), and nitrate has increased by $20 \%$ compared to the previous years (from about 20 to $25 \mathrm{mg} \mathrm{NO}_{3} \cdot \mathrm{L}^{-1}$ ) immediately below the Achères WWTP.

Dissolved oxygen and chlorophyll (a proxy for phytoplankton biomass) present parallel but complementary patterns. It has long been known that the former is controlled by both organic matter degradation and $\mathrm{NH}_{4}{ }^{+}$nitrification; the latter is dependent on $\mathrm{PO}_{4}{ }^{3-}$ uptake by algal growth. Oxygen increased steadily after the 1980s, and most remarkably in the past decade, while phytoplankton biomass has gradually decreased throughout the river stream, and very clearly in the estuarine area after 2007.

Finally, silica presents large interannual variations related to the flow regime, but unlike the other variables, it shows no obvious phases or turning points in the time series (Fig. $3 \mathrm{~g}$ ). On average, the concentration of silica fluctuates around $6.7 \pm 2.6 \mathrm{mg} \mathrm{SiO}{ }_{2} \cdot \mathrm{L}^{-1}$.

\subsection{Environmental Quality Standards}

The urgency for sustainable management and protection of water resources has led European water policies to establish a number of common criteria in terms of quality, and whenever relevant, quantity, to ensure that good status of surface water and groundwater is achieved. Environmental Quality Standards (hereafter, EQS) are set for this purpose, and provide concentration ranges coupled to status categories that give us a quick idea on how healthy or damaged the system is (EU-Directive 2008/105/EC). Figure 4 shows the evolution of oxygen and inorganic nutrients in terms of these quality standards. We calculated the number of samplings assigned to each quality category per year and plotted the results following the EQS colour codes. A timeline summarising important socio-ecological changes is plotted below as a reference. Details on the specific data and the EQS thresholds are provided in Table 2.

The EQS bar charts disclose a clear improvement in quality status for oxygen, ammonium and phosphate, the first two currently in good or very good conditions throughout the year. However, there is a concomitant worsening of water quality related to nitrate inputs, slightly 
reversed in the past few years following the implementation of denitrification procedures in 2012. With respect to nitrate, half of the samplings in 2011 fell within the "Poor Status" category and half of them within the "Moderate Status", and the balance has recently shifted to about 70\% "Moderate" versus 30\% "Poor", similar to the values observed during the late 1990s. Silica, which shows less depletion in the last few years due to lower phytoplankton development (Fig. 3), is not considered in the EQS as a target variable and is not displayed in Figure 4. Overall, this implies that the changes in nutrient concentrations we see in the profiles have indeed had a direct impact in terms of quality status, and point directly to the efficacy (or inefficacy) of certain management practices that will be discussed later.

Given that nutrient inputs are related to terrestrial activities and these are not homogeneously distributed across the basin, we further analysed whether major quality improvement or deterioration has occurred within specific locations or river sections. We selected a few stations representative of the six sections established and assessed the changes in concentrations and quality status per decade (for the 1980-2010 period, which is the most complete, Fig. 5).

The results show a recent convergence of the stations toward similar characteristics, i.e. similar polygon shapes. Regardless of the river section, after 2000 (and more so after 2010, not shown) we repeatedly observe low phosphate and ammonium values, and high oxygen and nitrate concentrations, while these very same stations presented clearly different situations in the previous decades. In the 1980-1990 period, there were contrasted shapes between the upper and lower estuary, and the river sections upstream of Poses (e.g. Caudebec versus Poses, or Poses versus Paris). These divergences persisted in the 1990-2000 period, although they were somewhat smoothed. Likewise, in the 1990s, chlorophyll was high downstream of Poses and low upstream, while after the year 2000 phytoplankton abundance was moderate to low throughout the whole stretch under study. It therefore looks like the heterogeneous patterns observed in the past, which tracked the neighbouring terrestrial activities, have faded, and the implementation of environmental plans has led to a more uniform situation along the river, because of less severe pressures from human activity.

\subsection{Annual nutrient loads and export to the estuary}

Going a step beyond, we examined the direct consequences of these concentration shifts for the estuary in terms of annual nutrient load, given that the total export of nutrients to estuarine waters - and ultimately to the adjacent marine system - is directly linked to longstudied algal blooms and eutrophication issues (Billen \& Garnier, 2007; Passy et al., 2016; Romero et al., 2013). Small changes in nutrient concentrations can indeed produce large excesses of nutrients (in absolute values, but also in terms of their ratios) at the river outlet, and hence potentially induce large effects in terms of eutrophication.

To account for the nutrient load that is entering the estuary, we calculated annual fluxes at Poses. Figure 6a shows the evolution of ammonium, nitrate and phosphate fluxes since the 1970s. The reduction of phosphate and ammonium inputs is manifest: ammonium has decreased from ca. $30 \mathrm{kTon} \mathrm{N} \cdot \mathrm{y}^{-1}$ in the $1970 \mathrm{~s}$ to $3 \mathrm{kTon} \mathrm{N} \cdot \mathrm{y}^{-1}$ in recent years. Similarly, phosphate has dropped from $8 \mathrm{kTon} \mathrm{P} \cdot \mathrm{y}^{-1}$ in the 1980 s to $1-2 \mathrm{kTon} \mathrm{P} \cdot \mathrm{y}^{-1}$ after 2010 . The opposite occurs for nitrate: inputs were $<50 \mathrm{kTon} \mathrm{N} \cdot \mathrm{y}^{-1}$ in the $1970 \mathrm{~s}$ (slightly higher than ammonium) but are currently $\sim 90 \mathrm{kTon} \mathrm{N} \cdot \mathrm{y}^{-1}$, rocketing to values $>100$ during wet years (e.g. $147 \mathrm{kTon} \mathrm{N} \cdot \mathrm{y}^{-1}$ in 2001, $116 \mathrm{kTon} \mathrm{N} \cdot \mathrm{y}^{-1}$ in 2013).

To pull apart the effect of flow variability, we plotted the annual nutrient fluxes versus the flow anomalies (the difference between the flow of a particular year and the average annual 
flow of the whole time series, as described in Fig. 2). Figure $6 b-d$ shows, for a given discharge, the net change in nutrient export. The results clearly show a positive linear relationship between river flow and nitrate - highlighting the contribution of diffuse sources - and a negative relationship with ammonium, the latter mostly coming from urban sources and diluted at high flows. Note, however, that current ammonium values ( $>2010)$ are steady regardless of the discharge, which suggests that they represent a baseline, i.e. the minimum flux attainable. In general, for a discharge of $13,000 \mathrm{Hm}^{3} \cdot \mathrm{y}^{-1}$ (close to the average of 14,700 $\mathrm{Hm}^{3} \cdot \mathrm{y}^{-1}$ ), the export of ammonium was $24 \mathrm{kTon} \mathrm{N}$ in 1975, 14 in 2004 and 4 in 2010; for that

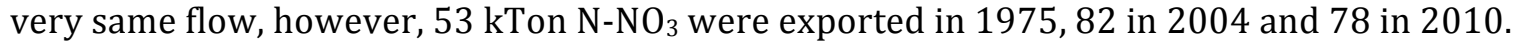
Thus, in terms of total nitrogen load, the $\mathrm{N}-\mathrm{NH}_{4}$ reduction is offset by the $\mathrm{N}-\mathrm{NO}_{3}$ increase, and no improvement is observed.

Phosphate is also positively correlated to river flow, although the relationship is weaker than that of nitrate, as shown by the scatter in the data. Phosphate comes from a mixture of diffuse and point sources, which have both decreased over time: the drop of $P$ fluxes at low flows points directly to the abatement of urban sources, while the decline at high flows (the slope is remarkably lower after the year 2000), evidences a reduction of diffuse agricultural inputs.

The plots are also useful to see the range of variability in nutrient exports for specific discharge values, and stress the impact during wet years, when $\mathrm{N}$ fluxes to the estuary may increase two-fold with regard to average values.

\subsection{Covariation of the main quality parameters}

We performed principal component analyses (PCA) to determine the main variability axes of the data set and to assess the covariation of quality variables (Fig. 7). Two main components explain $>50 \%$ of the total variability: Component 1 is strongly determined by the phosphate, ammonium, nitrate and oxygen values, and seems to describe an axis of point versus diffuse sources. Component 2 is mostly defined by the salinity and suspended matter concentration, which points to a geographical axis (estuary and lower reaches versus upper reaches). This is confirmed when we separate (e.g. by a colour scale) the data points according to the river section. Moreover, separating the data points per decade, it is clear that the first component tracks the temporal evolution fairly well, with the 1970s, 1980s and most of the 1990s points always located on the positive part of the axis, and all data points after the year 2000 located on the negative part.

\subsection{Seasonal and long-term variability}

As shown in Figs. 3-5, long-term changes are apparent for most variables along the river stretch under study, but intra-annual variability in the Seine is also large. We used STL filtering methods to decompose the time series and (1) to assess the relative importance of seasonal cycles in both estuarine and riverine stations; (2) to explore to what extent longterm variations exceed seasonal patterns and (3) to disclose long-term shifting patterns and inflection points. Figure 8 shows the long-term and seasonal components of the time series at five stations representative of different river sections. The percentage of variability explained by each component - for these and a few other stations - are detailed in Table 3 . They show that seasonal patterns in the estuary are generally less pronounced in terms of annual variability than those found upstream, notably for phosphate and nitrate, although differences are not as large as expected. Indeed, even though estuarine stations are subject to tides and influenced by marine intrusions - and therefore tend to present highly variable patterns - the 
data show low variability. This apparent regularity is possibly related to a constant sampling strategy preceding the marine ebb, from downstream to upstream locations. At Paris and Carrières, seasonal cycles account for about $25 \%$ of the annual variability (nutrients and oxygen averaged, Table 3), while this value is $20 \%$ at Honfleur.

Seasonality is clearly dominant over long-term patterns for silicate (on average $37 \%$ of the total $\mathrm{SiO}_{2}$ variability is related to the annual cycle) and for chlorophyll in the estuarine sections, where it accounts for $25 \%$ of the total variability. Instead, long-term trends prevail for phosphate, ammonium and nitrate $(56 \%, 51 \%$ and $54 \%$ of their total variability, respectively).

The STL results confirm that the sharpest turning points in the time series occurred in the mid-1990s and in the late 2000s. High values of ammonium and phosphate started to decrease in all river sections in the 1990s, while long-term nitrate-increasing trends show a steep decline recently, around the year 2007. Turning points are also visible in the seasonal cycles that shrink or expand in relation to major concentration changes. Interestingly, the seasonal cycles of nitrate have remained more or less constant at all stations except at Honfleur, the most downstream station, where tidal effects may have interfered in the analysis.

\section{DISCUSSION}

The Seine watershed plays a strategic role in France, constituting both an important population hub and a key industrial and commercial axis. It is hence a dynamic territory that has undergone constant transformations over the past 50 years, in parallel with the evolution of many other European regions.

\subsection{A 45-year trajectory}

This study is framed within the last stages described by Billen et al. (2007) and extends over a decade afterwards, which allows testing whether past trends remain valid and, most importantly, allows evaluating the impact of policies that entered into force later in time, such as the European Water Framework Directive (WFD, 2000/60/EC). Up to the year 2000, our results are consistent with the periods suggested by earlier authors. There is a clear turning point around the 1990s: progress in wastewater treatments and the ban of phosphates in household detergents explain the decrease in ammonium and phosphate loads, whereas nitrate inputs have increased, for the most part, owing to intensive agricultural practices. Billen et al. (2001) estimate that the use of nitrogen fertilisers increased nine-fold between the 1950s and the 1990s, from about $13 \mathrm{~kg} \mathrm{~N} \cdot \mathrm{ha}^{-1} \cdot \mathrm{yr}^{-1}$ in 1955 to $114 \mathrm{~kg} \mathrm{~N} \cdot \mathrm{ha}^{-1} \cdot \mathrm{yr}^{-1}$ in 1996 , and recent studies estimate that their use climbed to $190 \mathrm{~kg} \mathrm{~N} \cdot \mathrm{ha}^{-1} \cdot \mathrm{yr}^{-1}$ in the year 2000 and is presently around $160 \mathrm{~kg} \mathrm{~N} \cdot \mathrm{ha}^{-1} \cdot \mathrm{yr}^{-1}$ (Garnier et al., 2013b). These authors also underline the role played by wetland drainage programs in reducing natural denitrification processes. Artificial drainage, amply promoted in the Seine until the 1980s, sidesteps the filter effect of riparian strips and resulted in a loss of $\mathrm{N}$ retention capacity within the watershed (Billen \& Garnier, 2000).

The patterns described for the late 1990s were just the beginning of longer trends, which consolidated after 2000 and have mostly extended until a few years ago. Recent WWT upgrades prompted by European policies, including nitrification (fully implemented in Achères in 2007) and denitrification (up to 70\% of the $\mathrm{N}$ load has been denitrified since 2012 in Achères) have led to further $\mathrm{N}$ reductions that clearly appear in our profiles. The latest 
nutrient lowering has favoured a decrease of chlorophyll, and has suppressed the summer oxygen deficit in the estuary. Anoxic episodes, partly linked to the degradation of organic matter and partly to the nitrification of ammonium-rich effluents, occurred repeatedly in the Seine during the spring and summer months up to 2007 and were considered a typical feature of the ecological functioning of the system (Billen et al., 2001; Garnier et al., 2008). During the past decade, the application of WFD guidelines has forced supplementary carbon abatements and a $25 \%$ reduction of the wastewater volume, which, along with the $\mathrm{N}$ treatments, have contributed to better oxygenation (Garnier et al., 2008).

Technological advances have been effective in cutting down point sources from domestic and industrial origin, but nutrients from diffuse sources are proving difficult to hold in check. This is worrisome, given that European rivers receive, on average, $60-65 \%$ of total $\mathrm{N}$ pollution and ca. $45 \%$ of $P$ pollution from diffuse sources (EEA, 2005). In the Seine, only a 2$3 \%$ decrease in nitrate is currently observed with regard to what Billen et al. $(2001,2007)$ reported for 1998, even though control measures to reduce the overdosage of fertilisers have existed for over two decades (EC, 2010; Oenema et al., 2011).

According to Eurostat (http://appsso.eurostat.ec.europa.eu), the mean $\mathrm{N}$ surplus in agricultural soils in the EU-15 decreased from $65 \mathrm{~kg} \mathrm{~N}$ per ha in 1990 to $50 \mathrm{~kg} \mathrm{~N}$ per ha in 2000 , and recent values for France are on the order of $45 \mathrm{~kg} \mathrm{~N}$ per ha (2012). Significant reductions $(\sim-30 \%)$ have thus taken place, although the improvements may still be insufficient, or their consequences are not yet visible in freshwater systems. In Northern European countries, where environmental policies and regulatory practices are a few steps ahead, N-surplus reductions and complementary mitigation measures started in the 1980s and early 1990s, and the effects in freshwater quality were only apparent 10-20 years later (Bechmann et al., 2008; Ekholm et al., 2007; Ulén \& Fölster, 2007).

Besides the arguable efficacy of management measures, the delay in the behaviour of nutrients from diffuse sources reflects complex transfer processes and the lagged response of aquifers as compared to that of surface waters. Groundwater can have residence times of several decades (Alley et al., 2002; Wriedt \& Bouraoui, 2009) and up to 50 years in the case of the Seine Basin (Ledoux et al., 2007), which means that nitrate released in 2011, when nitrate concentration was at its maximum, was partly the aftermath of inadequate practices occurring in the 1990s. As a whole, the recent stabilisation of nitrate fluxes can be attributed to both changes in agricultural practices for the last two decades and to more recent advances in $\mathrm{N}$ treatment in Paris' WWTPs, the latter representing a small fraction of the total $\mathrm{N}$ fluxes, however.

On the other hand, polluted aquifers pose a serious health and environmental problem, as much as or more so than surface waters, for several reasons: (1) the nutrient overload to coastal systems is prolonged in time; (2) groundwaters form the summer base flow of rivers, which means that high nitrate concentrations are available in the summertime, a period of the year which is particularly sensitive to harmful algal blooms; (3) the remediation of groundwater is costly and technically challenging (EEA, 2005; 2010) and (4) most importantly, aquifers are a precious resource in many places where the freshwater supply depends almost entirely on groundwater. According to Grizzetti et al. (2011), about twothirds of the European population rely on groundwater for domestic uses.

\subsection{Coupled responses in the river and the estuary}

One of the advantages of the present study with regard to previous works is the comprehensive inclusion of data from freshwater and estuarine stations, which offers the 
possibility of testing if there is a decoupling between the two areas. Differences in the physical constraints are huge between the upper and lower sections under study, including the morphology of the riverbed, the neighbouring human pressure and the influence of tides and marine waters, so we expected a certain divergence in their long-term dynamics as well. The results show, however, that their evolution is fairly well matched. Although the nutrient and oxygen status were clearly different between stations up to the 1990s, they have all evolved synchronously toward common values. There are no or very slight delays in the turning points, and increasing/decreasing patterns are coincident throughout the stretch. This means that although intra-estuarine processes (e.g. adsorption, biological consumption, dilution and mixing with marine water masses) can alter the export of nutrients to the sea, these processes are not intense enough to decouple the dynamics of the estuary from that of the river. From a management perspective, mostly focused on the control of freshwaters, this implies that environmental policies are also positively affecting the quality status of the estuary. From a marine point of view, however, it means that the estuary is not able to further purify the water before it reaches the coastal zone.

The close connection between upstream and downstream nutrient dynamics is fundamentally due to the extreme artificialisation of the estuary, which has been deeply altered to accommodate large-scale commercial navigation and to control flood risks (Lesourd et al., 2001; Lesueur et al., 2006). Morphological changes have transformed marshlands into linear waterways, thus reducing the residence time in the estuary (currently on the order of 1-3 months, Garnier et al., 2008) and severely limiting its buffer capacity. A number of modelling studies assumed that the estuary's buffer role was indeed negligible (e.g. Cugier et al., 2005; Lancelot et al., 2011; Passy et al., 2013).

Garnier et al. (2010) tested the validity of that assumption and assessed the retention of $\mathrm{N}$, $\mathrm{P}$ and $\mathrm{Si}$ within the lower part of the estuary. These authors found that it played a limited role for Si and N (4\% and 7\% annual retention, respectively), but could retain up to $30 \%$ of inorganic $\mathrm{P}$ inputs. Their results, however, were based on only a few years - although contrasted in hydrology - and used a simplified description of the TMZ.

\subsection{Implications for management}

The temporal patterns observed in the Seine basin are common in many other European catchments (Bouraoui \& Grizzetti, 2011; Romero et al., 2013), yet the information available in most other rivers is remarkably less abundant. This is why the Seine offers a precious opportunity to explore the effectiveness of water policies and to envisage future prospects. From a management viewpoint, EQSs are efficient at setting up a basic common framework and at providing an idea on how severely human activities have impacted the ecosystem. Current regulations, however, fail to manage and prevent diffuse pollution (e.g. nitrate) that presents irregular patterns and sluggish changes extending over long time periods. Great inter-annual variability such as that related to dry and wet years, for instance, can mask subtle, continuing long-term trends. Very long data records, even longer than the record presented in this study, are required to disentangle these variations, but lengthy time series are seldom available.

Relevant policies for the control of freshwater quality in the European Union were approved in the 1990s as an urgent response to the worrying rapid degradation of surface water masses in many countries. The Nitrates Directive (91/676/EEC), aimed at reducing nitrate pollution from agricultural land, and the Urban Waste Water Treatment Directive (91/271/EEC), targeting pollution from industrial and domestic sewage, entered into force in 1991 and were followed shortly thereafter by the Integrated Pollution Prevention and Control 
Directive (96/61/EEC), which extended control measures to many other industrial sectors. Environmental action plans linked to these policies were projected and applied, in most cases, between the 1990s and the 2000s, which means that they have been in use for about 15-20 years and we can now have a reasonable idea on their appropriateness and efficacy.

First, the levels of compliance are heterogeneous. In the Seine, there has been a very high and efficient implementation of technological wastewater treatment solutions, but a much slower application of agri-environmental measures. This is common in many other basins, because the regulation of agri-environmental practices relies on political will, and its application is often delayed by a large number of farmers (OECD, 2007; Oenema et al., 2011 and references therein). As a consequence, point sources of ammonium and phosphate have been drastically reduced, and both variables today enjoy good or very good status, but nitrate from diffuse sources has largely increased with regard to the values observed in the $1980 \mathrm{~s}$. In addition, the overall efficacy and the time required to achieve significant quality improvements are very different. Advances in wastewater technologies have been progressively applied, but there is no delay in the effect once they are in use. On the contrary, terrestrial systems have a certain inertia that may slow down the effectiveness of agrienvironmental practices, as is the case of aquifers, discussed above, but also of nutrient storage and mobilisation processes within the soil, which depend on soil properties and usage during previous years (Cassman et al., 2002; Howden et al., 2010; USEPA, 2011).

The Water Framework Directive requires the achievement of good ecological potential of rivers across the EU by 2015. It also demands the achievement of good groundwater status by 2015 and the reversal of any significant and sustained upward trend in the concentration of pollutants. In the Seine, enormous advances have been made. Nutrient abatements have led to increases in oxygen levels and have reduced algal biomass, thus improving the general ecological status of the river, but the WFD requirements in terms of nutrients will not be fully achieved because high values of nitrate still persist in surface waters and are even higher in aquifers. Similar situations have been reported for the Loire (Minaudo et al., 2015), the Scheldt (Soetaert et al., 2006; Van Damme et al., 2005) and several rivers in Germany and the UK (Behrendt et al., 2002; Howden et al., 2010; Jackson et al., 2008). Jackson et al. (2008) even argue that, in Chalk catchments, the achievement of WFD levels may be unfeasible before the end of the century unless drastic measures (e.g. no agricultural N loading) are immediately applied.

Furthermore, improvements in nutrient status are not always directly conveyed to ecological status, because the response of the organisms depends on many other factors. In this regard, an important consequence of the different levels of efficacy resulting from the control measures of nutrients from point and diffuse sources is that current fluxes to the Seine Bight have severely biased N:P:Si ratios. This was pointed out in previous studies (e.g., Billen \& Garnier, 2007; Lancelot et al., 2007; Romero et al., 2013), yet the excess of N over Si, for instance, is barely taken into account.

High N:Si ratios in the Seine are the result of N increases rather than Si decreases. River damming and land use change, notably the transition from forest to cropland and the destruction of wetlands, can severely affect silica inputs according to the extensive reviews on the sources and biogeochemical cycling of silica provided in Conley (2002), Struyf \& Conley (2009) and Struyf et al. (2010). These land use transformations, however, occurred in our study area mostly before the 1970s; a few dams were built after that date, but they concerned shallow reservoirs with rather low overall retention, and therefore have a very limited effect on the Si concentration. As a result, silica inputs remain tightly related to natural rock weathering processes and do not show significant long-term variations. 
Biased nutrient ratios have been related to increased occurrences of harmful algal blooms, to shifts from diatoms to non-diatoms, and to several alterations of the aquatic food web (e.g., Glibert \& Burkholder 2006; Justić et al. 1995; Officer \& Ryther, 1980; Smayda, 1990; among many others). The annual flux of $\mathrm{N}$ to the Seine Bight is at present twice the value that would correspond to the Redfield ratios of $\mathrm{N}: \mathrm{P}, \mathrm{N}: \mathrm{Si}$, and given the strong correlation between nitrate and flow, the positive long-term flow anomaly could make the situation more severe.

Finally, the decrease of nitrate inputs observed across stations after 2010 remains questionable. It is not yet clear whether mitigation practices in agriculture - the rationalisation of fertiliser use, the expansion of cover crops and organic farming - are slowly giving results or if the nitrate decrease in the lower Seine results from recent wastewater treatment improvements. Nonetheless, because the wastewater treatment technology has reached its optimum (the 70\% denitrification in the Achères WWTP already requires the addition of methanol, and achieving a greater reduction would become counterproductive), current agri-environmental measures may not be enough to counteract the inertia of past years, given that the response time to decrease values from $>50$ to $<15 \mathrm{mg} \cdot \mathrm{L}^{-1}$ is several decades (Grizzetti et al., 2011).

This uncertainty in the response of freshwater systems is aggravated by the ill-defined effects of climate change, which could affect nutrient, oxygen, and phytoplankton concentrations through a number of processes, including increases in temperature, sea-level rise, changes in precipitation and runoff from land, wind patterns, and storminess. Changes in rainfall and sea-level rise may alter the water balance of the estuary: sustained periods of low precipitation may favour saltwater intrusions, alter food webs and affect the amount of time required to flush nutrients and contaminants from the system; on the contrary, increased rainfall and freshwater runoff would enhance diffuse nutrient fluxes (Scavia et al., 2002; Statham, 2012). Warmer conditions and possible lower summer discharges would affect stratification and oxygen concentration, and could support faster growth or a longer growing season for phytoplankton; further, temperatures might exceed the optimal growth temperature range of some organisms and induce drastic shifts in community composition.

To speed up the recovery and guarantee fresh water quality, several authors encourage the implementation of bold management measures, including less intensive and more diverse crop rotation strategies (Beaudoin et al., 2005; Robertson \& Vitousek, 2009), improved manure management (van Grinsven et al., 2015), the restoration of ponds (Passy et al., 2012; Garnier et al., 2014), the generalisation of organic farming (Thieu et al., 2010; Benoit et al., 2014) or even diet changes to reduce meat consumption (Billen et al., 2014; 2015). In light of these results, valiant environmental policies are the only possible way to prevent chronic pollution problems and truly restore the good ecological status of rivers and the neighbouring coastal zone.

\section{ACKNOWLEDGEMENTS}

This work was undertaken within the framework of the Scientific Program Seine-Aval, sponsored by the consortium GIP-Seine-Aval (http://seine-aval.crihan.fr/web/). The authors acknowledge the GIP-Seine-Aval for funding the work of Dr. E. Romero and the Federation Ilede-France for Research on the Environment (FIRE) for additional financial aid. This study also benefited from the emulation and data from the Emosem-Project (SeasEra), and the FLAM Project (Liteau-AESN). The study is supported by the French project RESET, coordinated by Josette Garnier (http://seine-aval.crihan.fr/web/pages.jsp?currentNodeId=189) and by the 
French Research Institutions (CNRS, UPMC, IRD) through the salaries of their staff researchers.

\section{REFERENCES}

Alley, W.M., Healy, R.W., LaBaugh, J.W., Reilly, T.E., 2002. Hydrology - Flow and storage in groundwater systems. Science 296, 1985-1990.

Beaudoin, N., Saad, J.K., Van Laethem, C., Machet, J.M., Maucorps, J., Mary, B., 2005. Nitrate leaching in intensive agriculture in Northern France: Effect of farming practices, soils and crop rotations. Agric Ecosyst Environ 111, 292-310.

Bechmann, M., Deelstra, J., Stalnacke, P., Eggestad, H.O., Oygarden, L., Pengerud, A., 2008. Monitoring catchment scale agricultural pollution in Norway: policy instruments, implementation of mitigation methods and trends in nutrient and sediment losses. Environmental Science \& Policy 11, 102-114.

Behrendt, H., Kornmilch, M., Opitz, D., Schmoll, O., Scholz, G., 2002. Estimation of the nutrient inputs into river systems - experiences from German rivers. Regional Environmental Change 3, 107-117.

Benoit, M., Garnier, J., Anglade, J., Billen, G., 2014. Nitrate leaching from organic and conventional arable crop farms in the Seine Basin (France). Nutr Cycl Agroecosyst, DOI 10.1007/s10705-014-9650-9.

Billen, G., Garnier, J., 2000. Nitrogen transfers through the Seine drainage network: a budget based on the application of the 'Riverstrahler' model. Hydrobiologia 410, 139-150.

Billen, G., Garnier, J., 2007. River basin nutrient delivery to the coastal sea: assessing its potential to sustain new production of non-siliceous algae. Mar Chem 106, 148-160.

Billen, G., Garnier, J., Ficht, A., Cun, C., 2001. Modeling the response of water quality in the Seine river estuary to human activity in its watershed over the last 50 years. Estuaries 24, 977-993.

Billen, G., Garnier, J., Némery, J., Sebilo, M., Sferratore, A., Barles, S., Benoit, P., Benoit, M., 2007. A long-term view of nutrient transfers through the Seine river continuum. Sci Total Environ 375, 80-97.

Billen, G., Lassaletta, L., Garnier, J., 2014. A biogeochemical view of the global agro-food system: Nitrogen flows associated with protein production, consumption and trade. Global Food Security 3, 209-219.

Billen, G., Lassaletta, L., Garnier, J., 2015. A vast range of opportunities for feeding the world in 2050: trade-off between diet, N contamination and international trade. Environ Res Lett 10,025001

Bouraoui, F., Grizzetti, B., 2011. Long term change of nutrient concentrations of rivers discharging in European seas. Sci Total Environ 409, 4899-4916.

Canton, M., Anschutz, P., Poirier, D., Chassagne, R., Deborde, J., Savoye, N., 2012. The buffering capacity of a small estuary on nutrient fluxes originating from its catchment (Leyre estuary, SW France). Estuarine Coastal Shelf Sci 99, 171-181.

Cassman, K.G., Dobermann, A., Walters, D.T., 2002. Agroecosystems, nitrogen-use efficiency, and nitrogen management. Ambio 31, 132-140.

Cleveland, R.B., Cleveland, W.S., McRae, J.E., Terpenning, I., 1990. STL: A seasonal-trend decomposition procedure based on Loess. Journal of Official Statistics 6, 3-73.

Cleveland, W.S., Devlin, S.J., 1988. Locally-weighted regression: An approach to regression analysis by local fitting. Journal of the American Statistical Association 83, 596-610.

Conley, D.J., 2002. Terrestrial ecosystems and the global biogeochemical silica cycle. Global Biogeochem Cycles 16, 1121. doi:10.1029/2002GB001894. 
Cugier, P., Billen, G., Guillaud, J.F., Garnier, J., Ménesguen, A., 2005. Modelling the eutrophication of the Seine Bight (France) under historical, present and future riverine nutrient loading. Journal of Hydrology 304, 381-396.

EC, 2010. Report from the Commission to the Council and the European Parliament on implementation of Council Directive 91/676/EEC concerning the protection of waters against pollution caused by nitrates from agricultural sources for the period 20042007.

EEA, 2005. The European Environment, State and Outlook 2005 (SOER 2005). European Environment Agency, Copenhagen.

EEA, 2010. The European Environment, State and Outlook 2010 (SOER 2010). European Environment Agency, Copenhagen.

Ekholm, P., Granlund, K., Kauppila, P., Mitikka, S., Niemi, J., Rankinen, K., Räike, A., Räsänen, J., 2007. Influence of EU policy on agricultural nutrient losses and the state of receiving surface waters in Finland. Agric Food Sci 16, 282-300.

Etcheber, H., Taillez, A., Abril, G., Garnier, J., Servais, P., Moatar, F., Commarieu, M.-V., 2007. Particulate organic carbon in the estuarine turbidity maxima of the Gironde, Loire and Seine estuaries: origin and lability. Hydrobiologia 588, 245-259.

Even, S., Thouvenin, B., Bacq, N., Billen, G., Garnier, J., Guezennec, L., Blanc, S., Ficht, A., Le Hir, P., 2007. An integrated modelling approach to forecast the impact of human pressure in the Seine estuary. Hydrobiologia 588, 13-29.

Fisson, C., Leboulenger, F., Lecarpentier, T., Moussard, S., Ranvier, G., 2014. L'estuaire de la Seine : état de santé et évolution. Programme scientifique Seine-Aval, Issue 3-1, 48 pp.

Foussard, V., Cuvilliez, A., Fajon, P., Fisson, C., Lesueur, P., Macur, O., 2010. Évolution morphologique d'un estuaire anthropisé de 1800 à nos jours. Programme scientifique Seine-Aval, Issue 2-3, 43 pp.

Garnier, J., Billen, G., Even, S., Etcheber, H., Servais, P., 2008. Organic matter dynamics and budgets in the turbidity maximum zone of the Seine Estuary (France). Estuarine Coastal Shelf Sci 77, 150-162.

Garnier, J., Billen, G., Némery, J., Sebilo, M., 2010. Transformations of nutrients (N, P, Si) in the turbidity maximum zone of the Seine estuary and export to the sea. Estuarine Coastal Shelf Sci 90, 129-141.

Garnier, J., Billen, G., Vilain, G., Benoit, M., Passy, P., Tallec, G., Tournebize, J., Anglade, J., Billy, C., Mercier, B., Ansart, P., Azougui, A., Sebilo, M., Kao, C., 2014. Curative vs. preventive management of nitrogen transfers in rural areas: Lessons from the case of the Orgeval watershed (Seine River basin, France). J Environ Manage 144, 125-134.

Garnier, J., Passy, P., Thieu, V., Callens, J., Silvestre, M., Billen, G., 2013a. Fate of nutrients in the aquatic continuum of the Seine River and its estuary: Modelling the impacts of human activity changes. In: Bianchi, T. S., Allison, M. A., Cai, W.-J. (Eds.) The watershed biogeochemical dynamics at large river-coastal interfaces: Linkages with global climate change. Cambridge University Press, 671 pp. ISBN 978-1-107-20257-7.

Garnier, J., Vilain, G., Silvestre, M., Billen, G., Jehanno, S., Poirier, D., Martinez, A., Decuq, C., Cellier, P., Abril, G., 2013b. Budget of methane emissions from soils, livestock and the river network at the regional scale of the Seine basin (France). Biogeochemistry 116, 199-214.

Glibert, P.M., Burkholder, J.M., 2006. The complex relationships between increasing fertilization of the earth, coastal eutrophication and proliferation of harmful algal blooms. In: Granéli, E., Turner, J. (Eds.) Ecology of Harmful Algae. Springer, Heidelberg, pp. 341-354.

Grizzetti, B., Bouraoui, F., Billen, G., van Grinsven, H., Cardoso, A.C., Thieu, V., Garnier, J., Curtis, C., Howarth, R., Johnes, P., 2011. Nitrogen as a threat to European water quality. In: 
Sutton, M.A., Howard, C.M., Erisman, J.W., Billen, G., Bleeker, A., Grennfelt, P., van Grinsven, H., Grizzetti, B. (Eds.) The European nitrogen assessment. Cambridge University Press, pp 379-404.

Howden, N.J.K., Burt, T.P., Worrall, F., Whelan, M.J., Bieroza, M., 2010. Nitrate concentrations and fluxes in the River Thames over 140 years (1868-2008): are increases irreversible? Hydrological Processes 24, 2657-2662.

Jackson, B.M., Browne, C.A., Butler, A.P., Peach, D., Wade, A.J., Wheater, H.S., 2008. Nitrate transport in Chalk catchments: monitoring, modelling and policy implications. Environmental Science \& Policy 11, 125-135.

Justić, D., Rabalais, N.N., Turner, R.E., Dortch, Q., 1995. Changes in nutrient structure of riverdominated coastal waters - stoichiometric nutrient balance and its consequences. Estuarine Coastal Shelf Sci 40, 339-356.

Lafite, R., Garnier, J., De Jonge, V., 2007. Consequences of estuarine management on hydrodynamics and ecological functioning. ECSA 38th Symposium - Rouen 2004 Coorganisation Seine-Aval Programme and ECSA. Hydrobiologia 588, 1-302.

Lafite, R., Romaña, L.A., 2001. A man-altered macrotidal estuary: The Seine estuary (France): Introduction to the special issue. Estuaries 24, 939-939.

Lancelot, C., Gypens, N., Billen, G., Garnier, J., Roubeix, V., 2007. Testing an integrated riverocean mathematical tool for linking marine eutrophication to land use: The Phaeocystisdominated Belgian coastal zone (Southern North Sea) over the past 50 years. J Mar Syst 64, 216-228.

Lancelot, C., Thieu, V., Polard, A., Garnier, J., Billen, G., Hecq, W., Gypens, N., 2011. Cost assessment and ecological effectiveness of nutrient reduction options for mitigating Phaeocystis colony blooms in the Southern North Sea: An integrated modeling approach. Sci Total Environ 409, 2179-2191.

Ledoux, E., Gomez, E., Monget, J.M., Viavattene, C., Viennot, P., Ducharne, A., Benoit, M., Mignolet, C., Schott, C., Mary, B., 2007. Agriculture and groundwater nitrate contamination in the Seine basin. The STICS-MODCOU modelling chain. Sci Total Environ 375, 33-47.

Le Hir, P., Silva Jacinto, R., Thouvenin, B., Guézennec, L., Bassoulet, P., Cugier, P., Leboulenger, F., Hocdé, R., Lesueur, P., Romaña, L. A., 1999. Courants, vagues et marées : les mouvements de l'eau. ISBN 2-84433-028-2 Seine Aval Programme. Ifremer, Quae Editions, 31 pp (Chapter 2).

Lesourd, S., Lesueur, P., Brun-Cottan, J.C., Auffret, J.P., Poupinet, N., Laignel, B., 2001. Morphosedimentary evolution of the macrotidal Seine estuary subjected to human impact. Estuaries 24, 940-949.

Lesueur, P., Lesourd, S., Auffret, J.-P., Avoine, J., Bassoullet, Ph., Brun-Cottan, J.-C., Dupont, J.-P., Guézennec, L., Lafite, R., Poupinet, N., 2006. Sables, chenaux, vasières: dynamique des sédiments et évolution morphologique. ISBN 2-84433-028-2 Seine Aval Programme. Ifremer, Quae Editions, 39 pp (Chapter 3).

Li, Y., Campbell, E.P., Haswell, D., Sneeuwjagt, R.J., Venables, W.N., 2003. Statistical forecasting of soil dryness index in the southwest of Western Australia. For Ecol Manage 183, 147157.

Lloyd, C.E.M., Freer, J.E., Collins, A.L., Johnes, P.J., Jones, J.I., 2014. Methods for detecting change in hydrochemical time series in response to targeted pollutant mitigation in river catchments. Journal of Hydrology 514, 297-312.

Lu, H., Li, Y., Clilverd, M.A., Jarvis, M.J., 2012. Trend and abrupt changes in long-term geomagnetic indices. Journal of Geophysical Research-Space Physics 117.

Massei, N., Laignel, B., Deloffre, J., Mesquita, J., Motelay, A., Lafite, R., Durand, A., 2010. Longterm hydrological changes of the Seine River flow (France) and their relation to the 
North Atlantic Oscillation over the period 1950-2008. International Journal of Climatology 30, 2146-2154.

Meybeck, M., de Marsily, G., Fustec, E., 1998. La Seine en son bassin: fonctionnement écologique d'un système fluvial anthropisé. Elsevier, Paris.

Minaudo, C., Meybeck, M., Moatar, F., Gassama, N., Curie, F., 2015. Eutrophication mitigation in rivers: 30 years of trends in spatial and seasonal patterns of biogeochemistry of the Loire River (1980-2012). Biogeosciences 12, 2549-2563.

Naeher, S., Huguet, A., Roose-Amsaleg, C.L., Laverman, A.M., Fosse, C., Lehmann, M.F., Derenne, S., Zopfi, J., 2015. Molecular and geochemical constraints on anaerobic ammonium oxidation (anammox) in a riparian zone of the Seine Estuary (France). Biogeochemistry 123, 237-250.

Némery, J., Garnier, J., 2007. Typical features of particulate phosphorus in the Seine estuary (France). Hydrobiologia 588, 271-290.

OECD, 2007. Instrument Mixes for Environmental Policy. OECD Publishing, Paris.

Oenema, O., Bleeker, A., Braathen, N.A., Budňáková, M., Bull, K., Čermák, P., Geupel, M., Hicks, K., Hoft, R., Kozlova, N., Leip, A., Spranger, T., Valli, L., Velthof, G., Winiwarter, W., 2011. Nitrogen in current European Policies. In: Sutton, M.A., Howard, C.M., Erisman, J.W., Billen, G., Bleeker, A., Grennfelt, P., van Grinsven, H., Grizzetti, B. (Eds.) The European Nitrogen Assessment. Cambridge University Press, pp 62-81.

Officer, C.B., Ryther, J.H., 1980. The Possible Importance of Silicon in Marine Eutrophication. Mar. Ecol. Prog. Ser. 3, 83-91.

OSPAR, 1998. Principles of the comprehensive study on riverine inputs and direct discharges (RID). OSPAR Commission, Reference number: 1998-5, 17 pp.

Passy, P., Garnier, J., Billen, G., Fesneau, C., Tournebize, J., 2012. Restoration of ponds in rural landscapes: Modelling the effect on nitrate contamination of surface water (the Seine River Basin, France). Sci Total Environ 430, 280-290.

Passy, P., Gypens, N., Billen, G., Garnier, J., Thieu, V., Rousseau, V., Callens, J., Parent, J.Y., Lancelot, C., 2013. A-model reconstruction of riverine nutrient fluxes and eutrophication in the Belgian Coastal Zone since 1984. J Mar Syst 128, 106-122.

Passy, P., Le Gendre, R., Garnier, J., Cugier, P., Callens, J., Paris, F., Billen, G., Riou, P., Romero, E., 2016. Eutrophication modelling chain for improved management strategies to prevent algal blooms in the Seine Bight. Mar. Ecol. Prog. Ser., in press, doi: 10.3354/meps11533

Qian, S.S., Borsuk, M.E., Stow, C.A., 2000. Seasonal and long-term nutrient trend decomposition along a spatial gradient in the Neuse River watershed. Environ Sci Technol 34, 44744482.

Robertson, G.P., Vitousek, P.M., 2009. Nitrogen in agriculture: balancing the cost of an essential resource, Annual Review of Environment and Resources 34, 97-125.

Romero, E., Garnier, J., Lassaletta, L., Billen, G., Le Gendre, R., Riou, P., Cugier, P., 2013. Largescale patterns of river inputs in southwestern Europe: seasonal and interannual variations and potential eutrophication effects at the coastal zone. Biogeochemistry 113, 481-505.

Seebens, H., Straile, D., Hoegg, R., Stich, H.-B., Einsle, U., 2007. Population dynamics of a freshwater calanoid copepod: Complex responses to changes in trophic status and climate variability. Limnol Oceanogr 52, 2364-2372.

Smayda, T.J., 1990. Novel and nuisance phytoplankton blooms in the sea: evidence for a global epidemic. In: Granéli, E., Sundström, B., Edler, R., Anderson, D.M. (Eds.) Toxic marine phytoplankton. Elsevier, New York, pp 29-40.

Soetaert, K., Middelburg, J.J., Heip, C., Meire, P., Van Damme, S., Maris, T., 2006. Long-term change in dissolved inorganic nutrients in the heterotrophic Scheldt estuary (Belgium, The Netherlands). Limnol Oceanogr 51, 409-423. 
Scavia, D., Field, J.C., Boesch, D.F., Buddemeier, R.W., Burkett, V., Cayan, D.R., Fogarty, M., Harwell, M.A., Howarth, R.W., Mason, C., Reed, D.J., Royer, T.C., Sallenger, A.H., Titus, J.G., 2002. Climate change impacts on US coastal and marine ecosystems. Estuaries 25, 149164.

Statham, P.J., 2012. Nutrients in estuaries - An overview and the potential impacts of climate change. Sci Total Environ 434, 213-227.

Struyf, E., Conley, D.J., 2009. Silica: an essential nutrient in wetland biogeochemistry. Front Ecol Environ 7, 88-94.

Struyf, E., Smis, A., Van Damme, S., Garnier, J., Govers, G., Van Wesemael, B., Conley, D.J., Batelaan, O., Frot, E., Clymans, W., Vandevenne, F., Lancelot, C., Goos, P., Meire, P., 2010. Historical land use change has lowered terrestrial silica mobilization. Nature Communications 1:129. doi: 10.1038/ncomms1128.

Thieu, V., Billen, G., Garnier, J., Benoît, M., 2010. Nitrogen cycling in a hypothetical scenario of generalised organic agriculture in the Seine, Somme and Scheldt watersheds. Regional Environmental Change, 1-12.

Ulén, B., Fölster, J., 2007. Recent trends in nutrient concentrations in Swedish agricultural rivers. Sci Total Environ 373, 473-487.

USEPA, 2011. Reactive nitrogen in the United States: An analysis of inputs, flows, consequences and management options. USEPA Science Advisory Board, Washington DC.

Van Damme, S., Struyf, E., Maris, T., Ysebaert, T., Dehairs, F., Tackx, M., Heip, C., Meire, P., 2005. Spatial and temporal patterns of water quality along the estuarine salinity gradient of the Scheldt estuary (Belgium and The Netherlands): results of an integrated monitoring approach. Hydrobiologia 540, 29-45.

van Grinsven, H.J.M., Bouwman, L., Cassman, K.G., van Es, H.M., McCrackin, M.L., Beusen, A.H.W., 2015. Losses of ammonia and nitrate from agriculture and their effect on nitrogen recovery in the European Union and the United States between 1900 and 2050. J Environ Qual 44, 356-367.

Wriedt, G., Bouraoui, F., 2009. Towards a large scale assessment of water availability in Europe. European Commission Joint Research Centre, Luxembourg. 


\section{TABLES AND FIGURE CAPTIONS}

\section{Tables}

Table 1. Basic characteristics of the Seine basin (stream length, population, population density, wastewater treatment capacity). SEINE refers to the whole basin, while LOW ST refers to the lowest stream reach (our study area), from Paris down to the estuary.

\begin{tabular}{lcccc}
\hline & $\begin{array}{c}\text { Length } \\
(\mathrm{km})\end{array}$ & $\begin{array}{c}\text { Population } \\
\left(10^{6} \text { inhab. }\right)\end{array}$ & $\begin{array}{c}\text { Density } \\
(\text { inhab./km²) }\end{array}$ & $\begin{array}{c}\text { WWT capacity } \\
\left(10^{6} \text { equiv. inhab. }\right)\end{array}$ \\
\hline SEINE & 767 & 17 & $195^{*}$ & $11.3^{\ddagger}$ \\
LOW ST & 360 & 12 & $230^{* *}$ & $7.6^{*}$ \\
\hline
\end{tabular}

*Garnier et al., 2010; Naeher et al., 2015

** Passy et al., 2016

‡Billen et al., 2001 
Table 2. (I) Nutrient thresholds and their corresponding colour codes, as established in EU and French environmental regulations. These thresholds have been used in Figures 4 and 5 . (II) For each variable, the percentage of samplings per decade that falls within each status category. "N Samplings" refers to the total number of samplings available. Data refer to all quality stations analysed together.

(I)

\begin{tabular}{|c|c|c|c|c|}
\hline Status & $\mathrm{O}_{2}(\mathrm{mg} / \mathrm{L})$ & $\mathrm{PO}_{4}^{3-}(\mathrm{mg} / \mathrm{L})$ & $\mathrm{NH}_{4}{ }^{+}(\mathrm{mg} / \mathrm{L})$ & $\mathrm{NO}_{3}^{-}(\mathrm{mg} / \mathrm{L})$ \\
\hline High & $\geq 8$ & $\leq 0.1$ & $\leq 0.1$ & $\leq 2$ \\
\hline Good & $\geq 6$ & $\leq 0.5$ & $\leq 0.5$ & $\leq 10$ \\
\hline Moderate & $\geq 4$ & $\leq 1$ & $\leq 2$ & $\leq 25$ \\
\hline Poor & $\geq 3$ & $\leq 2$ & $\leq 5$ & $\leq 50$ \\
\hline Bad & $<3$ & $>2$ & $>5$ & $>50$ \\
\hline
\end{tabular}

(II)

\begin{tabular}{|c|c|c|c|c|c|c|c|}
\hline Variable & Decade & High & Good & Moderate & Poor & Bad & N Samplings \\
\hline \multirow[t]{6}{*}{$\mathrm{O}_{2}(\mathrm{mg} / \mathrm{L})$} & $<1970$ & $11 \%$ & $22 \%$ & $21 \%$ & $11 \%$ & $36 \%$ & 1354 \\
\hline & $1970-1980$ & $20 \%$ & $28 \%$ & $21 \%$ & & $22 \%$ & 3166 \\
\hline & $1980-1990$ & $31 \%$ & $35 \%$ & $20 \%$ & $6 \%$ & $8 \%$ & 4278 \\
\hline & $1990-2000$ & $41 \%$ & $28 \%$ & $18 \%$ & $5 \%$ & $8 \%$ & 4497 \\
\hline & $2000-2010$ & $62 \%$ & $23 \%$ & $11 \%$ & $2 \%$ & $2 \%$ & 4079 \\
\hline & $>2010$ & $73 \%$ & $24 \%$ & $4 \%$ & $0 \%$ & $0 \%$ & 956 \\
\hline \multirow[t]{6}{*}{$\mathrm{PO}_{4}{ }^{3-}(\mathrm{mg} / \mathrm{L})$} & $<1970$ & - & - & -1 & - & - & - \\
\hline & $1970-1980$ & $0 \%$ & $9 \%$ & $20 \%$ & $30 \%$ & $41 \%$ & 2606 \\
\hline & $1980-1990$ & $0 \%$ & $2 \%$ & $14 \%$ & $42 \%$ & $41 \%$ & 4349 \\
\hline & $1990-2000$ & $0 \%$ & $10 \%$ & $28 \%$ & $40 \%$ & $22 \%$ & 4555 \\
\hline & $2000-2010$ & $1 \%$ & $56 \%$ & $36 \%$ & $6 \%$ & $1 \%$ & 4116 \\
\hline & $>2010$ & $3 \%$ & $86 \%$ & $11 \%$ & $0 \%$ & $0 \%$ & 921 \\
\hline \multirow[t]{6}{*}{$\mathrm{NH}_{4}+(\mathrm{mg} / \mathrm{L})$} & $<1970$ & $0 \%$ & $6 \%$ & $76 \%$ & $18 \%$ & $0 \%$ & 120 \\
\hline & $1970-1980$ & $5 \%$ & $15 \%$ & $40 \%$ & $32 \%$ & $8 \%$ & 2826 \\
\hline & $1980-1990$ & $5 \%$ & $16 \%$ & $50 \%$ & $24 \%$ & $5 \%$ & 4343 \\
\hline & $1990-2000$ & $8 \%$ & $19 \%$ & $41 \%$ & $25 \%$ & $7 \%$ & 4533 \\
\hline & $2000-2010$ & $18 \%$ & $34 \%$ & $35 \%$ & $10 \%$ & $3 \%$ & 3926 \\
\hline & $>2010$ & $40 \%$ & $47 \%$ & $12 \%$ & $1 \%$ & $0 \%$ & 921 \\
\hline \multirow[t]{6}{*}{$\mathrm{NO}_{3}-(\mathrm{mg} / \mathrm{L})$} & $<1970$ & $1 \%$ & $19 \%$ & $80 \%$ & $0 \%$ & $0 \%$ & 120 \\
\hline & $1970-1980$ & $1 \%$ & $11 \%$ & $83 \%$ & $5 \%$ & $0 \%$ & 2873 \\
\hline & $1980-1990$ & $0 \%$ & $1 \%$ & $91 \%$ & $8 \%$ & $0 \%$ & 4364 \\
\hline & $1990-2000$ & $0 \%$ & $1 \%$ & $71 \%$ & $28 \%$ & $0 \%$ & 4587 \\
\hline & $2000-2010$ & $0 \%$ & $0 \%$ & $50 \%$ & $50 \%$ & $0 \%$ & 4115 \\
\hline & $>2010$ & $0 \%$ & $0 \%$ & $64 \%$ & $36 \%$ & $0 \%$ & 921 \\
\hline
\end{tabular}


Table 3. Seasonal and long-term decomposition of the time series at several stations representative of the six river sections defined in the text. Time series analysis and decomposition were performed following the STL method (full details are given in the Materials \& Methods section). Seasonal refers to the percentage of variability explained by the seasonal adjustment, and Long-term indicates the percentage of variability accounted for by the long-term trend.

\begin{tabular}{|c|c|c|c|c|c|c|c|c|}
\hline \multicolumn{3}{|c|}{ Station } & \multirow{2}{*}{$\begin{array}{c}\mathbf{O}_{2} \\
31 \%\end{array}$} & \multirow{2}{*}{$\begin{array}{l}\text { Chl } \\
9 \%\end{array}$} & \multirow{2}{*}{$\frac{\mathrm{PO}_{4}{ }^{3-}}{6 \%}$} & \multirow{2}{*}{$\begin{array}{c}\mathbf{S i O}_{2} \\
39 \%\end{array}$} & \multirow{2}{*}{$\frac{\mathbf{N H}_{4}{ }^{+}}{12 \%}$} & \multirow{2}{*}{$\begin{array}{l}\mathrm{NO}_{3} \\
13 \%\end{array}$} \\
\hline \multirow{7}{*}{ 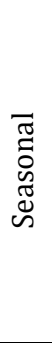 } & $\mathrm{S} 1$ & Honfleur & & & & & & \\
\hline & $\mathrm{S} 1$ & Tancarville & $32 \%$ & $32 \%$ & $9 \%$ & $42 \%$ & $10 \%$ & $8 \%$ \\
\hline & $\mathrm{S} 2$ & Caudebec & $39 \%$ & $33 \%$ & $3 \%$ & $37 \%$ & $8 \%$ & $6 \%$ \\
\hline & S3 & Rouen & $44 \%$ & $20 \%$ & $17 \%$ & $32 \%$ & $5 \%$ & $7 \%$ \\
\hline & $\mathrm{S} 4$ & Poses & $40 \%$ & $33 \%$ & $17 \%$ & $42 \%$ & $12 \%$ & $14 \%$ \\
\hline & S5 & Carrières & $32 \%$ & $9 \%$ & $12 \%$ & $43 \%$ & $17 \%$ & $21 \%$ \\
\hline & S6 & Paris & $51 \%$ & $5 \%$ & $13 \%$ & $26 \%$ & $4 \%$ & $30 \%$ \\
\hline \multirow{7}{*}{ 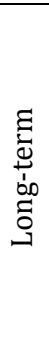 } & S1 & Honfleur & $44 \%$ & $20 \%$ & $58 \%$ & $22 \%$ & $54 \%$ & $57 \%$ \\
\hline & $\mathrm{S} 1$ & Tancarville & $50 \%$ & $18 \%$ & $67 \%$ & $23 \%$ & $63 \%$ & $54 \%$ \\
\hline & $\mathrm{S} 2$ & Caudebec & $46 \%$ & $23 \%$ & $75 \%$ & $26 \%$ & $63 \%$ & $62 \%$ \\
\hline & S3 & Rouen & $33 \%$ & $17 \%$ & $58 \%$ & $28 \%$ & $64 \%$ & $61 \%$ \\
\hline & S4 & Poses & $37 \%$ & $17 \%$ & $52 \%$ & $12 \%$ & $49 \%$ & $52 \%$ \\
\hline & S5 & Carrières & $49 \%$ & $24 \%$ & $50 \%$ & $8 \%$ & $41 \%$ & $52 \%$ \\
\hline & S6 & Paris & $12 \%$ & $27 \%$ & $35 \%$ & $5 \%$ & $26 \%$ & $43 \%$ \\
\hline
\end{tabular}




\section{Figure captions}

Figure 1. Map of the Seine basin showing the study area (the lower Seine, Paris to the estuary) and the network of water quality (pink) and gauging (blue) stations. The area is split into six different sections according to several physico-chemical and geographical characteristics (see Materials \& Methods for a complete description).

Figure 2. Seine River discharge at Poses, at the estuary entrance. (a) The black line shows the daily flow values of an average year (data for the 1970-2014 period) and the grey lines show the corresponding standard deviation. (b) Annual discharge anomalies at Poses (i.e. difference between the annual discharge and the mean annual discharge of the entire time series). Wet years are shown in blue and dry years in yellow. The red lines indicate the value of one standard deviation.

Figure 3. Profiles (1970-2013) of ammonium, nitrate, phosphate, silicate, dissolved oxygen and chlorophyll throughout the 45 sampling stations, from Paris (kilometric point 0 ) to Honfleur (kilometric point 355). The time series of river flow at Poses during the same period is shown on the top left corner.

Figure 4. Percentage of samplings per year (1970-2013) that fall within the five categories of the Environmental Quality Status (EQS) scale, as established in European and French regulations. Concentration thresholds per category are described in Table 2. Top to bottom: dissolved oxygen, ammonium, nitrate and phosphate. Data from all stations are pooled. The timeline on the bottom features some important morphological and socio-ecological changes.

Figure 5. Evolution of nutrients, chlorophyll and oxygen in several stations representative of the six river sections established. The axes are coloured following the EQS colour scale of the European and French regulations. The units and the range of values per axis are shown for Honfleur and are identical for all stations. Note that the oxygen and the silica axes are reversed, so that the lowest values are on the outside, and the highest on the inside. The lines represent averages per decade.

Figure 6. (a) Annual flux of nutrients at the entrance of the estuary (Poses). (b-d) The same annual nutrient fluxes plotted against their corresponding flow anomalies (dQ). As specified in the text, flow anomalies correspond to the difference between the flow of a particular year and the average annual flow of the whole time series. Dots are coloured according to the decade.

Figure 7. Principal component analysis of all available data (all stations, all years). Dots are coloured as a function of the river section (left) or the decade (right).

Figure 8. The results of the STL decomposition for four different variables (phosphate, ammonium, nitrate and dissolved oxygen) at five stations (Honfleur, Caudebec, Poses, Carrières, Paris). Left to right: the long-term trend component, the seasonal component of the three riverine stations, the seasonal component of the two estuarine stations. To ease comparisons, the envelopes of the seasonal cycles are coloured. All variables are in units of $\mathrm{mg} / \mathrm{L}$. 


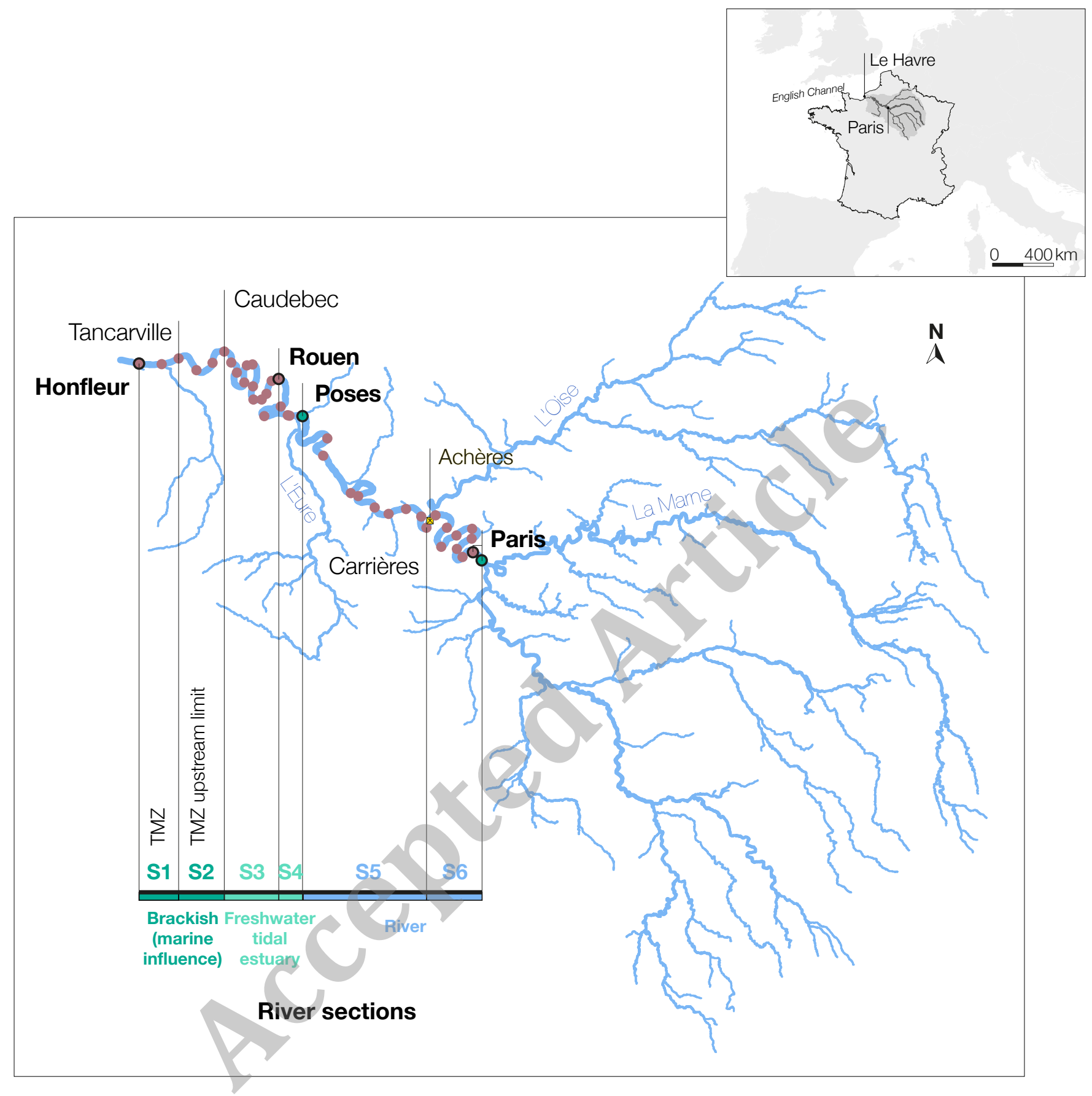

Figure 1 
a

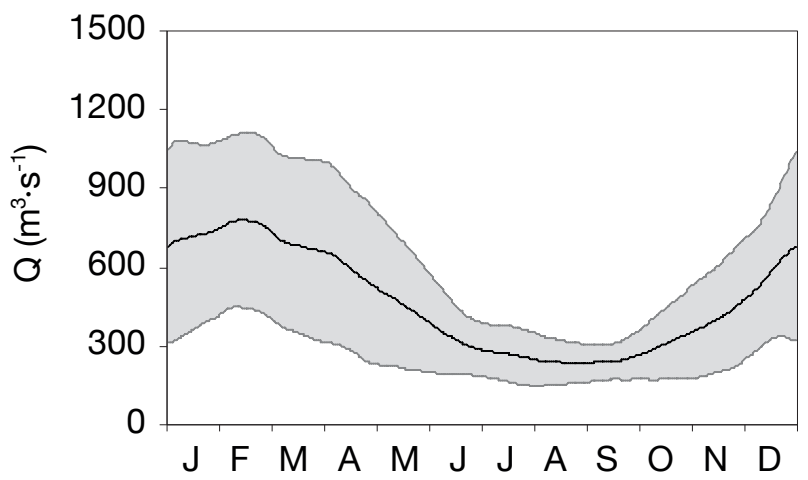

b

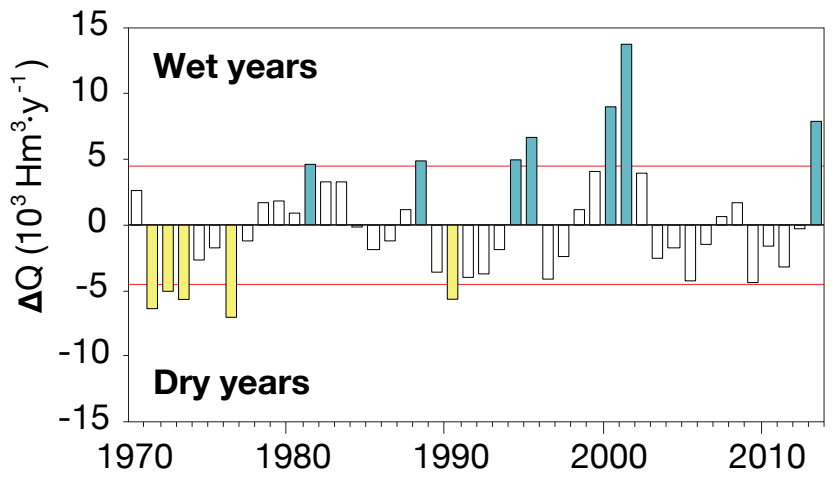

Figure 2 

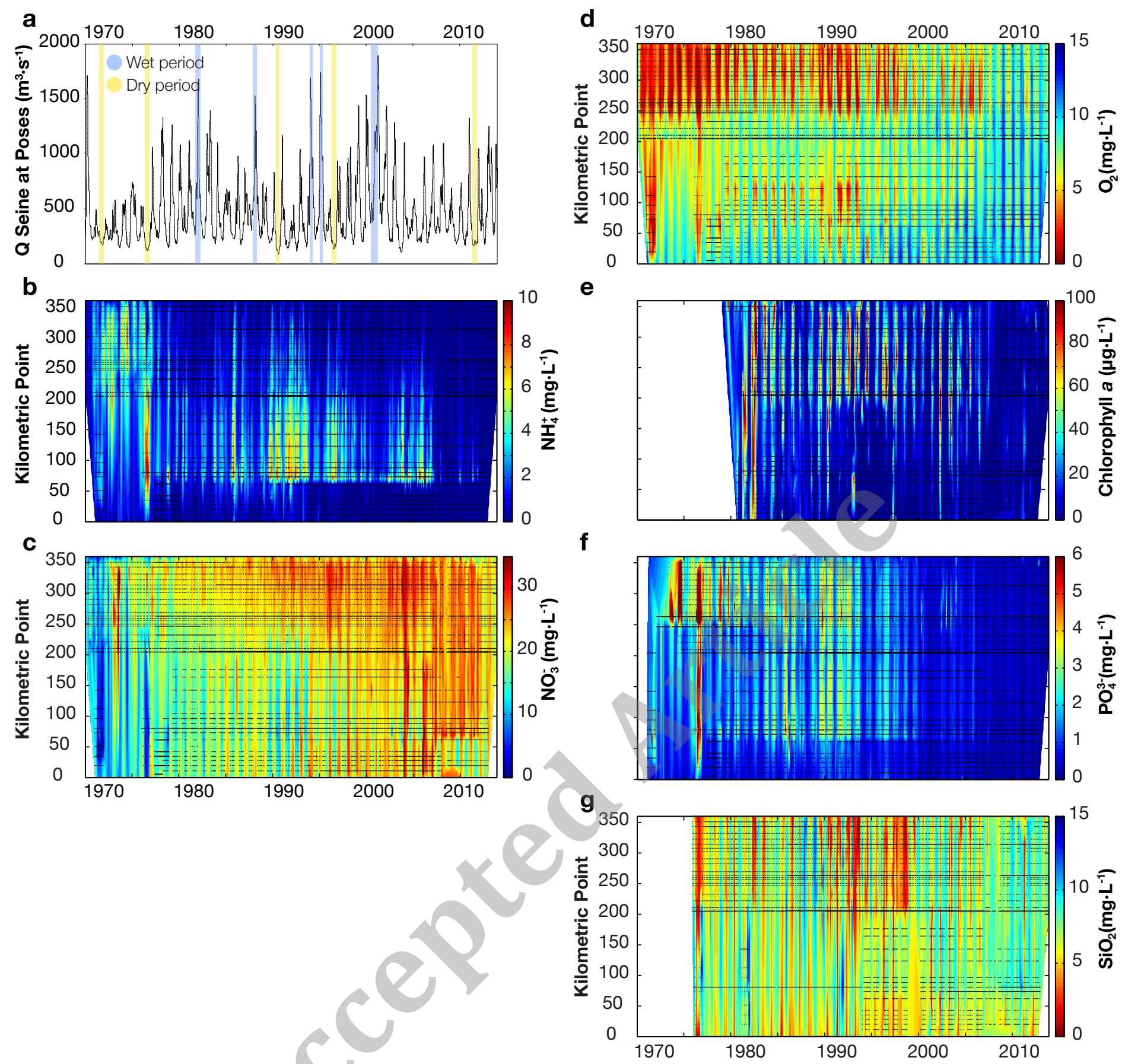

Figure 3 


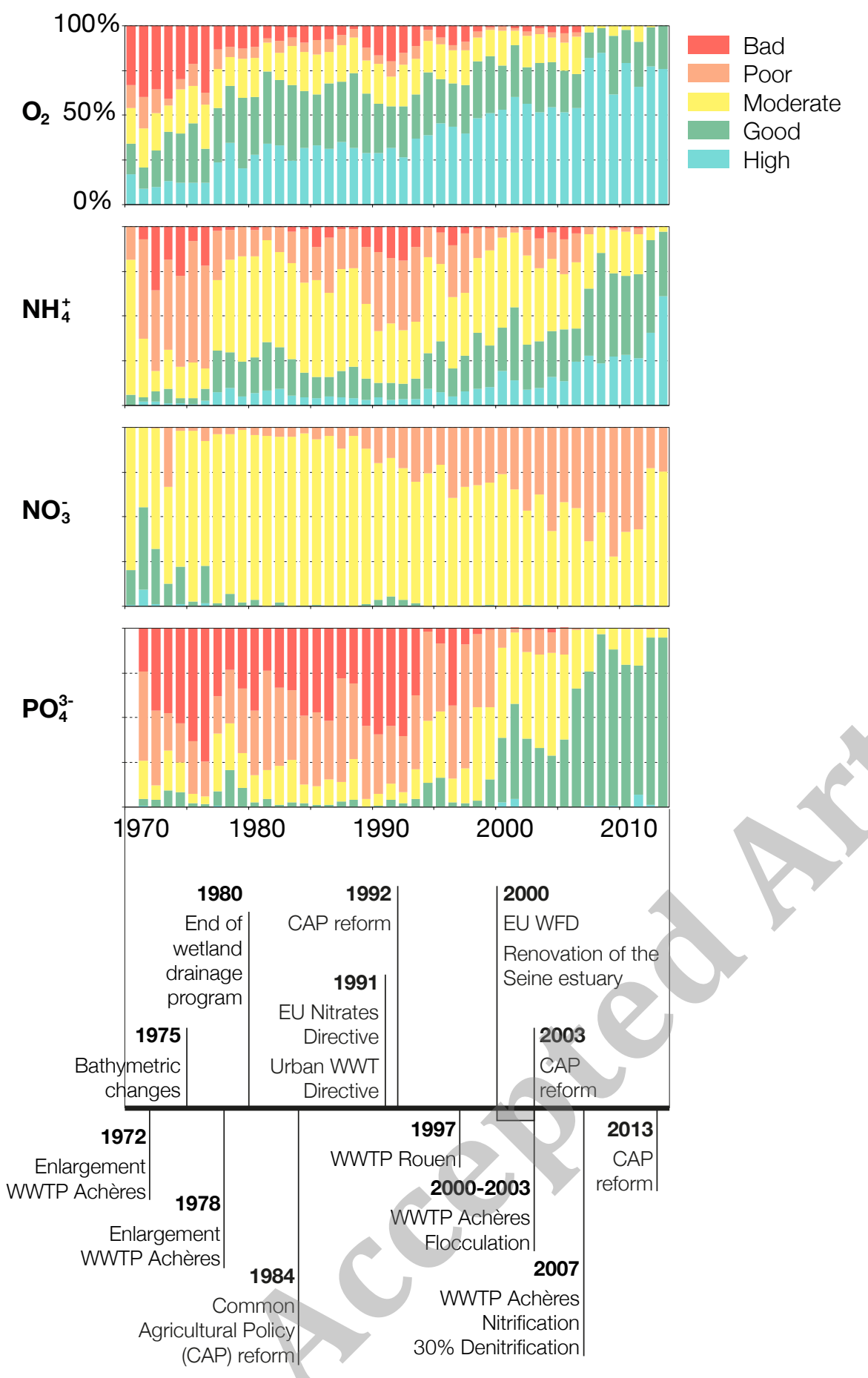

Morphological / land use / policy changes

Figure 4 


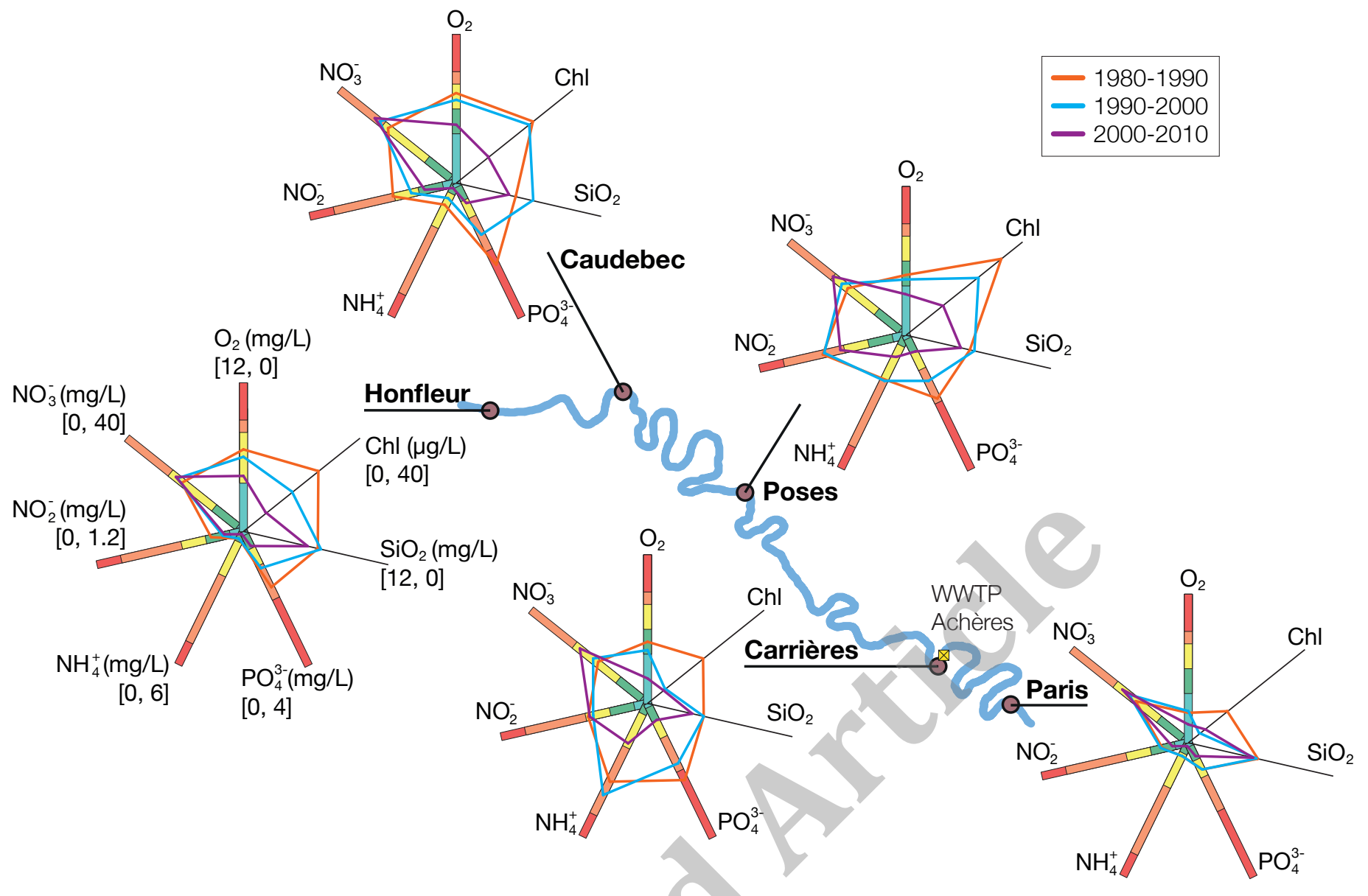

Figure 5 
a

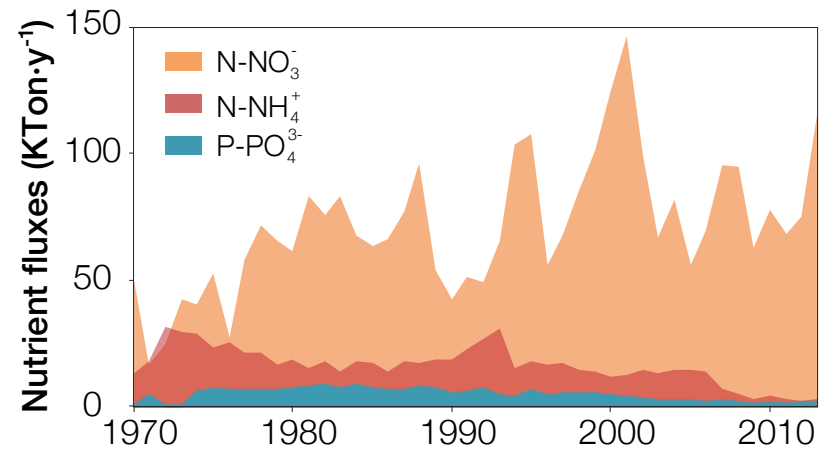

b

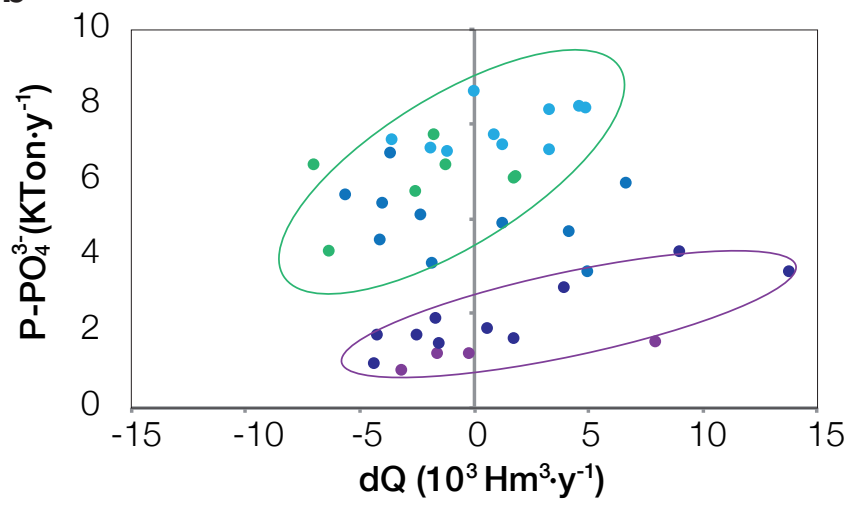

c

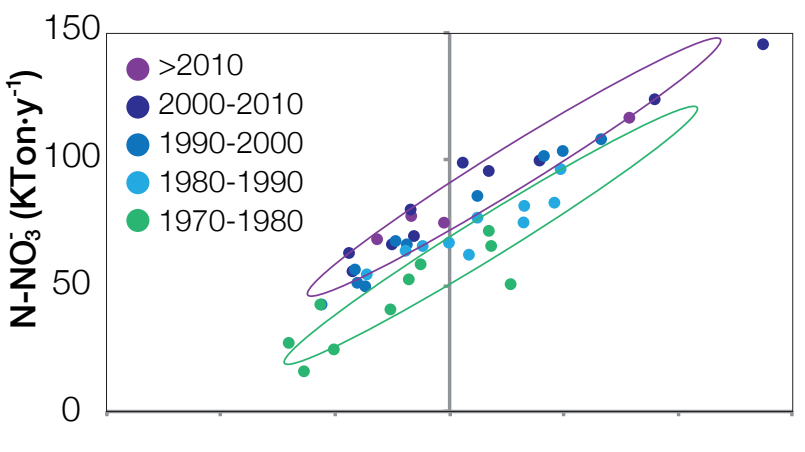

d

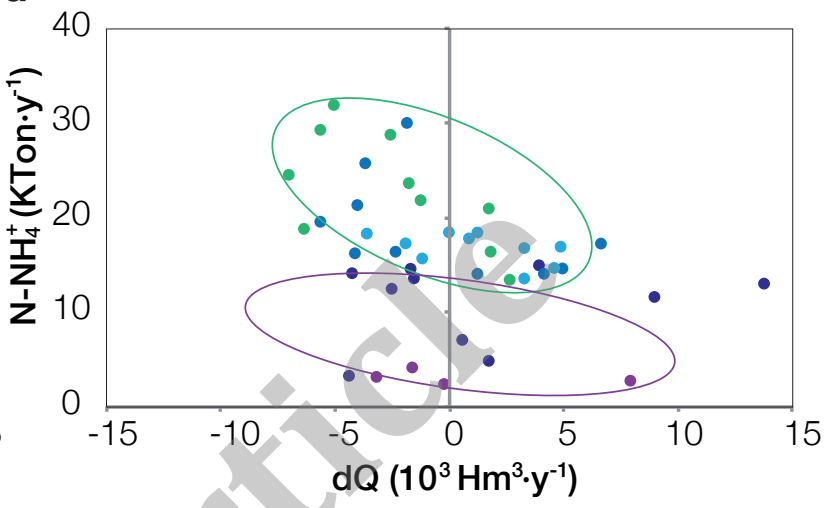

Figure 6 

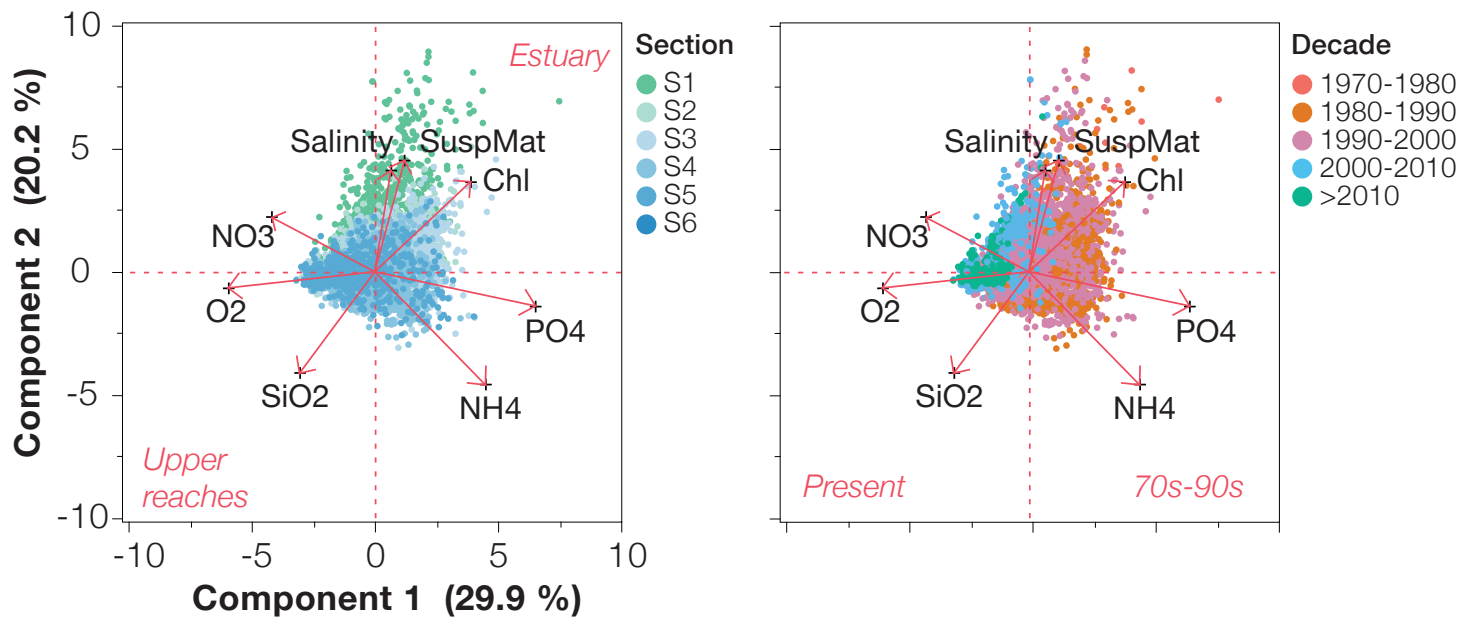

Figure 7 


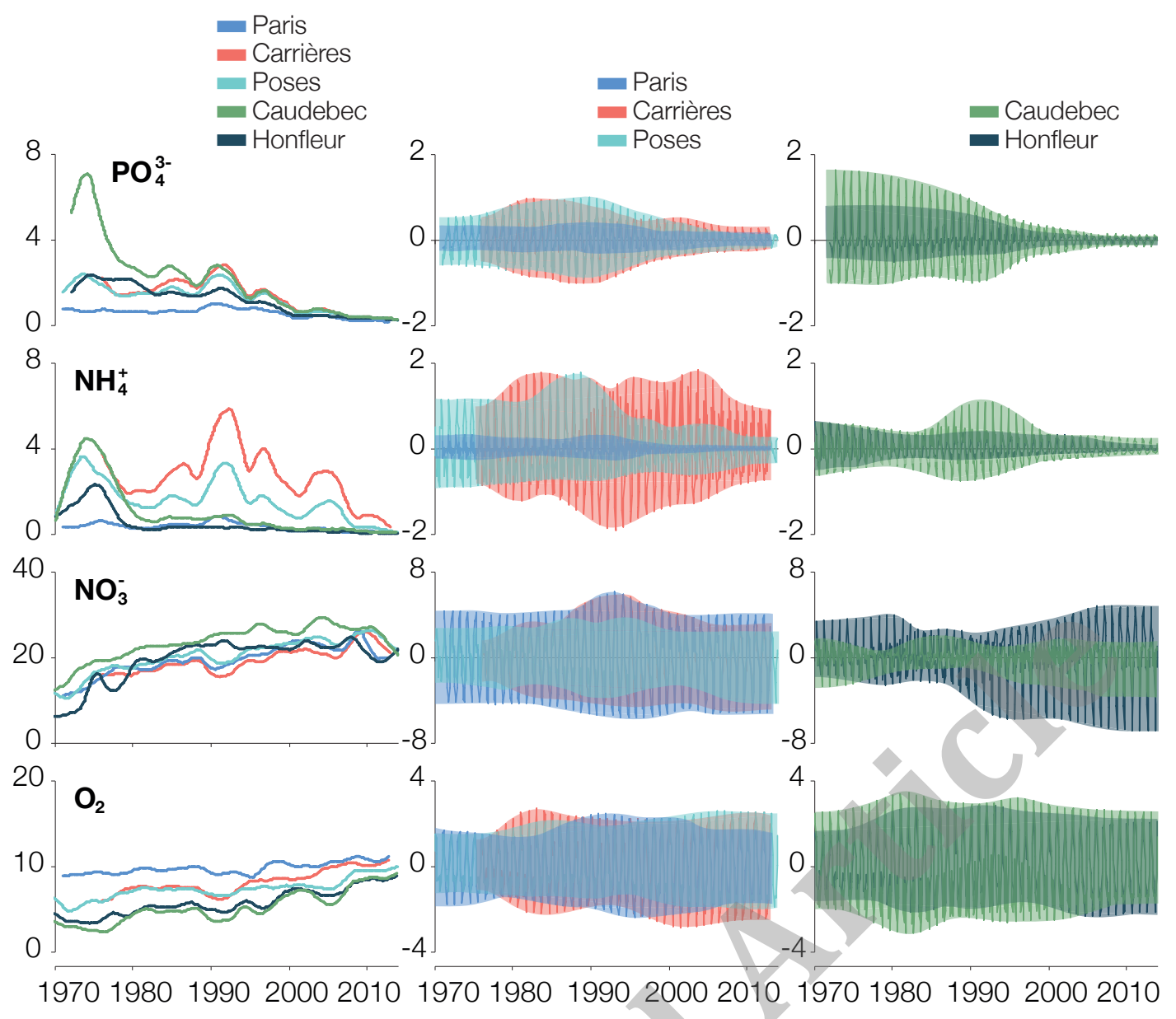

Figure 8 